\title{
Pelatihan Pembuatan Media Pembelajaran IPA Sederhana Bagi Guru IPA SD di Kabupaten Sleman
}

\section{The Training in Producing of Simple Science Intruction Media for Science Teacher in Sleman District}

\author{
Yusman Wiyatmo*, Bambang Ruwanto, Suparno, dan Jumadi \\ *Universitas Negeri Yogyakarta,08122778263, email: yusman_wiyatmo@uny.ac.id
}

\begin{abstract}
Abstrak
Pengabdian kepada masyarakat ini bertujuan untuk: 1) memberikan pengetahuan bagi guru IPA SD untuk merancang media pembelajaran IPA sederhana, 2) melatih keterampilan guru IPA untuk membuat media pembelajaran IPA sederhana, dan 3) melatih keterampilan guru IPA dalam menggunakan media pembelajaran IPA sederhana. Metode yang digunakan adalah dengan memberikan pelatihan kepada 7 guru IPA SD di Kabupaten Sleman tentang merancang, membuat, dan menggunakan alat peraga IPA sederhana. Pelatihan dilakukan di Ruang Perpustkaan Fisika pada tanggal 4 November 2016. Hasil pengabdian pada masyarakat menunjukkan bahwa: 1) peserta memiliki pengetahuan dalam merancang alat peraga, 2) peserta memiliki keterampilan dalam merancang alat peraga IPA, dan 3) peserta terampil menggunakan alat peraga IPA.
\end{abstract}

Kata kunci: pelatihan, media pembelajaran, IPA

\section{Abstract}

This service community is aimed to : 1) give knowledge for science teachers for designing of scince simple instrucion media, 2) trainee science teachers to design the instruction media, and 3) trainee the science teachers for using instruction media. The method used in this activity is trainning for 15 science teacher in Sleman district. The trainning is conducted in Library of Physics Education Department at November $4^{\text {nd }} 2016$. The results: 1) trainee have knowledge about instructional media, 2) trainee have skills to design the science instructional media, and 3) trainee have skills using the science intructional media.

Key words: trainning, instructional media, science

\section{PENDAHULUAN}

Berdasarkan hasil observasi di beberapa Sekolah Dasar di lingkungan Kabupaten Sleman diperoleh informasi bahwa sebagian besar sekolah sudah memiliki laboratorium IPA yang memadai namun alat-alat laboratorium yang dimiliki kurang tertata dan terradministrasi dengan baik. Dengan perkataan lain dapat diungkap bahwa alat-alat laboratorium belum dikelola dengan baik oleh pengelola laboratorium. Hal ini antara lain disebabkan oleh beberapa hal sebagai berikut: 1) Guru yang diserahi tugas untuk mengelola laboratorium cukup disibukkan dengan kegiatan belajar mengajar di kelas, 2) Kurangnya kesadaran guru untuk menggunakan alat-alat peraga IPA dalam kegiaatan belajar mengajar di kelas, 3) Kurangnya pengetahuan pengelola laboratorium tetang manajemen penggunaan dan perawatan alat-alat laboratorium, 4) Masih jarang guru-guru dalam membelajarkan IPA menggunakan metode ilmiah yang menuntut kegiatan praktik di laboratorium, dan 5) Masih rendahnya motivasi guru untuk mengembangkan alatalat peraga IPA sederhana yang dapat dimanfaatkan untuk menunjang kegiatan 
belajar mengajar, serta 6) Penggunaan alatalat laboratorium IPA untuk PBM di kelas masih belum optimal.

Berdasarkan

permasalahanpermasalahan yang muncul tersebut maka dalam rangka untuk memberikan bekal pengetahuan tentang pembuatan media pembelajran IPA bagi guru-guru IPA SD di lingkungan Kabupaten Sleman diperlukan kegitan pelatihan.

Tujuan kegiatan pengabdian pada masyarakat ini adalah sebagai berikut: 1) Memberikan pengetahuan bagi guru IPA SD untuk merancang media pembelajaran IPA sederhana, 2) Melatih keterampilan guru IPA untuk membuat media pembelajaran IPA sederhana, dan 3) Melatih keterampilan guru IPA dalam menggunakan media pembelajaran IPA sederhana.

Adapun manfaat kegiatan pengabdian masysarakat ini adalah:1) Bagi peserta pelatihan, kegiatan ini bermanfaat memberikan bekal pengetahuan dan keterampilan dalam merancang, membuat, dan menggunakan media pembelajaran IPA sederhana, dan 2) Bagi Tim Pengabdi, kegiatan ini bermanfaat untuk mensosialisasikan ilmu pengetahuan dan kegiatan-kegaiatan laboratorium Fisika kepada khalayak masyarakat pendidikan.

\section{SOLUSI/TEKNOLOGI}

Tahapan-tahapan

kegiatan pengabdian masyarakat untuk memberikan solusi bagi khalayak sasaran dapat dideskripsikan sebagai berikut: 1) Melaksanakan musyawarah tim pengabdi unuk membahas tentang materi pelatihan, peserta, waktu pelatihan, tempat pelatihan, dan sarana/prasarana yang dibutuhkan, 2) Mengembangkan instrumen pengabdian masyarakat berupa: modul Percobaan IPA dari Bahan Lingkungan Untuk Pembelajaran IPA SD yang berisi 14 jenis percobaan, Lembar Kinerja Peserta, dan angket respon peserta pelatihan untuk umpan balik, 3) Menentukan peserta pelatihan yang terdiri dari 15 peserta dengan skala prioritas yakni diutamakan peserta dipilih dari guru-guru IPA yang betul-betul membutuhkan pelatihan ini, 4) Membuat surat undangan untuk disebarkan kepada para peserta yang telah ditentukan, 5) Mengedarkan surat undangan ke lokasi sekolah oleh laboran/teknisi, 6) Melaksanakan kegiatan pengabdian dengan memberikan pelatihan merancang, membuat, dan menggunakan alat peraga IPA kepada peserta, dan 7) Memberikan angket respon perserta tentang pentingnya pelatihan, manfaat pelatihan, kesesuaian waktu pelatihan, materi pelatihan, struktur kegiatan pelatihan, dan saran-saran terhadap kegiatan pelatihan.

\section{HASIL DAN DISKUSI}

Kegiatan pengabdian pada masyarakat ini dilaksanakan pada hari Jumat tanggal 4 November 2016 di ruang perpustakaan jurdik fisika FMIPA UNY. Kegiatan dimulai pukul 13.00 s/d 16.30 WIB. Undangan diberikan kepada 15 guru IPA SD di Kabupaten Sleman dan dihadiri oleh 7 orang guru IPA SD.

Pada sesi pertama disajikan materi tentang perancangan dan pembuatan alat peraga konveksi udara dan listri statis dengan bahan botol plastik bekas, sedotan minuman, dan balon karet oleh Ketua Pengabdi. Selanjutnya materi kedua tentang alat peraga tegangan permukaan zat cair disajikan oleh Anggota Pengabdi 1. Pada sesi ketiga disajikan materi alat peraga sel Volta oleh Anggota Pengabdi 2, dan pada sesi terakhir disajikan materi alat peraga motor listrik oleh Anggota Pengabdi 3. Selanjutnya pada Gambar 1 berikut disajikan foto kegiatan pelaksanaan pengabdian.

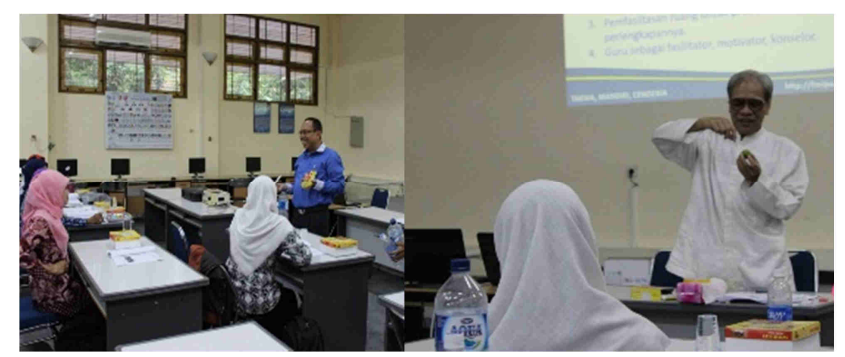


Gambar 1. Tim Pengabdi menyajikan materi alat peraga konveksi udara alat peraga sel Volta.

Peserta pelatihan merasa tertarik pada materi-materi yang disajikan oleh para penyaji. Mereka senang dan merasa menemukan hal-hal yang baru yang sebelumnya tidak pernah mereka duga. Alat peraga IPA ternyata dapat dibuat dan barang-barang bekas yang ada di sekitar kita seperti botol plastik, sedotan plastik, kaleng bekas, dll. Setelah menjadi alat peraga, barang-barang tersebut dapat bermanfaat untuk menunjukkan gejala IPA yang sesungguhnya secara langsung kepada siswa, sehingga dengan menggunakan alat peraga IPA sederhana tersebut pembelajaran menjadi lebih bermakna [1]. Selanjutnya pada Gambar 2 berikut disajikan aktivitas peserta dalam kegiatan pengabdian.

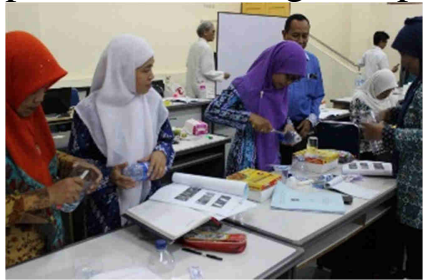

(a)

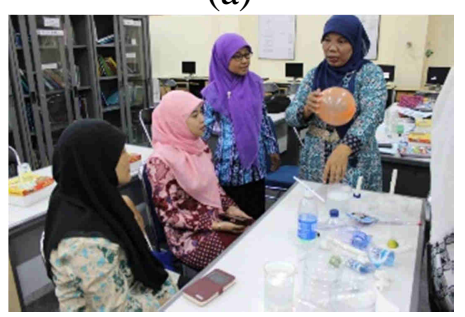

(b)

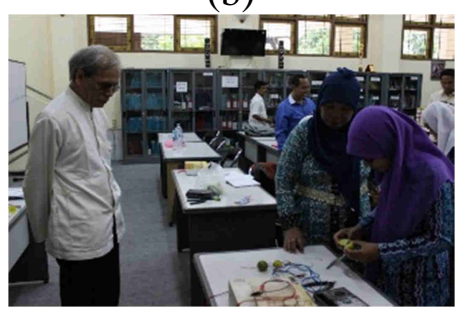

(c)

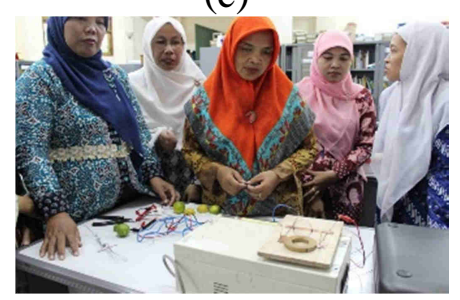

(d)
Gambar 2. (a) Peserta pelatihan sedang membuat alat peraga konveksi udara, (b). Peserta pelatihan sedang memperagakan gejala listrik statis dengan balon karet dan sedotan plastik, (c) Peserta pelatihan merangkai percobaan motor listrik, dan (d) Peserta pelatihan memperhatikan cara kerja motor listrik.

Pada saat kegiatan pelatihan berlangsung, diadakan penilaian kinerja yang mencakup aspek, kerjasama dalam kelompok, keaktifan dalam bekerja, dan kualitas alat peraga yang dihasilkan, serta kesungguhan dalam bekerja. Hasil penilaian kinerja peserta pelatihan disajikan pada Tabel 1 sbb:

Tabel 1. Rangkuman Hasil Penilaian Kinerja Guru IPA SD Kabupaten Sleman dalam Kegiatan Pembuatan Alat Peraga IPA

\begin{tabular}{|c|c|c|c|c|c|c|}
\hline $\begin{array}{c}\text { Kelom } \\
\text {-pok }\end{array}$ & $\begin{array}{c}\text { Kerj } \\
\text { asam } \\
\text { a }\end{array}$ & $\begin{array}{c}\text { Kea } \\
\text { ktifa } \\
\mathrm{n}\end{array}$ & $\begin{array}{c}\text { Kesu } \\
\text { nggu } \\
\text { han }\end{array}$ & $\begin{array}{c}\text { Kual } \\
\text { itas } \\
\text { Prod } \\
\text { uk }\end{array}$ & $\begin{array}{c}\text { Skor } \\
\text { Rera } \\
\text {-ta }\end{array}$ & $\begin{array}{c}\text { Inter- } \\
\text { pretasi }\end{array}$ \\
\hline 1 & 4 & 4 & 3 & 4 & $\mathbf{3 , 7 5}$ & $\begin{array}{c}\text { Sangat } \\
\text { Baik }\end{array}$ \\
\hline 2 & 4 & $\mathbf{4}$ & 3,7 & 3,7 & $\mathbf{3 , 8 5}$ & $\begin{array}{c}\text { Sangat } \\
\text { Baik }\end{array}$ \\
\hline 3 & 4 & 4 & 3,7 & 4 & $\mathbf{3 , 9 3}$ & $\begin{array}{c}\text { Sangat } \\
\text { Baik }\end{array}$ \\
\hline $\begin{array}{c}\text { Skor } \\
\text { Rerata }\end{array}$ & $\mathbf{4}$ & $\mathbf{4}$ & $\mathbf{3 , 4 7}$ & $\mathbf{3 , 9}$ & $\mathbf{3 , 8 4}$ & $\begin{array}{c}\text { Sangat } \\
\text { Baik }\end{array}$ \\
\hline $\begin{array}{c}\text { Interp } \\
\text { retasi }\end{array}$ & $\begin{array}{c}\text { Sang } \\
\text { at } \\
\text { Baik }\end{array}$ & $\begin{array}{c}\text { Sang } \\
\text { at } \\
\text { Baik }\end{array}$ & $\begin{array}{c}\text { Sang } \\
\text { at } \\
\text { Baik }\end{array}$ & $\begin{array}{c}\text { Sang } \\
\text { at } \\
\text { Baik }\end{array}$ & $\begin{array}{c}\text { Sang } \\
\text { at } \\
\text { Baik }\end{array}$ & \\
\hline
\end{tabular}

Di akhir kegiatan pembelajaran diberikan angket respon peserta terhadap pelaksanaan kegiatan pelatihan. Hasil analisis respon peserta secara singkat disajikan pada Tabel 2 sbb:

Tabel 4. Skor Respon Peserta Terhadap Pelaksanaan Kegiatan Pelatihan Pembuatan Alat peraga IPA Sederhana

\begin{tabular}{|l|l|c|c|c|}
\hline No & Pernyataan & \multicolumn{3}{|c|}{ Skor } \\
\cline { 3 - 5 } & Total & $\begin{array}{c}\text { Rera- } \\
\text { ta }\end{array}$ & $\begin{array}{c}\text { Inter- } \\
\text { pretasi }\end{array}$ \\
\hline 1 & $\begin{array}{l}\text { Materi pelatihan } \\
\text { yang }\end{array}$ & 28 & 4 & $\begin{array}{c}\text { Sanga } \\
\text { t Baik }\end{array}$ \\
\hline
\end{tabular}




\begin{tabular}{|c|c|c|c|c|}
\hline & $\begin{array}{l}\text { disampaikan } \\
\text { bermanfat bagi } \\
\text { saya sebagai } \\
\text { guru IPA SD. }\end{array}$ & & & \\
\hline 2 & $\begin{array}{l}\text { Alokasi waktu } \\
\text { pelatihan sesuai } \\
\text { dengan materi } \\
\text { yang disajikan }\end{array}$ & 23 & 3,29 & Baik \\
\hline 3 & $\begin{array}{l}\text { Instruktur } \\
\text { pelatihan } \\
\text { menguasai } \\
\text { materi yang } \\
\text { disajikan. }\end{array}$ & 28 & 4 & $\begin{array}{l}\text { Sanga } \\
\text { t Baik }\end{array}$ \\
\hline 4 & $\begin{array}{l}\text { Metode } \\
\text { pelatihan yang } \\
\text { digunakan } \\
\text { dengan praktik } \\
\text { langsung } \\
\text { membuat alat } \\
\text { peraga sesuai } \\
\text { dengan tujuan } \\
\text { pelatihan. }\end{array}$ & 27 & 3,86 & $\begin{array}{l}\text { Sanga } \\
\text { t Baik }\end{array}$ \\
\hline 5 & $\begin{array}{l}\text { Cara penyajian } \\
\text { materi pelatihan } \\
\text { bervariasi } \\
\text { sehingga tidak } \\
\text { membosankan. }\end{array}$ & 27 & 3,86 & $\begin{array}{l}\text { Sanga } \\
\text { t Baik }\end{array}$ \\
\hline 6 & $\begin{array}{l}\text { Fasilitas yang } \\
\text { disediakan } \\
\text { selama } \\
\text { pelatihan } \\
\text { memadai. } \\
\end{array}$ & 27 & 3,86 & $\begin{array}{l}\text { Sanga } \\
\text { t Baik }\end{array}$ \\
\hline 7 & $\begin{array}{l}\text { Setelah } \\
\text { mengikuti } \\
\text { pelatihan, saya } \\
\text { mendapatkan } \\
\text { pengetahuan/wa } \\
\text { wasan baru } \\
\text { tentang alat } \\
\text { peraga IPA } \\
\text { sederhana. }\end{array}$ & 27 & 3,86 & $\begin{array}{l}\text { Sanga } \\
\text { t Baik }\end{array}$ \\
\hline 8 & $\begin{array}{l}\text { Setelah } \\
\text { mengikuti } \\
\text { pelatihan, saya } \\
\text { menjadi lebih } \\
\text { terampil dalam } \\
\text { membuat alat } \\
\text { peraga IPA } \\
\text { sederhana. }\end{array}$ & 22 & 3,14 & Baik \\
\hline 9 & $\begin{array}{l}\text { Dalam kegiatan } \\
\text { pelatihan, saya } \\
\text { mendapatkan } \\
\text { tantangan untuk } \\
\text { dapat berhasil }\end{array}$ & 26 & 3,71 & $\begin{array}{l}\text { Sanga } \\
\text { t Baik }\end{array}$ \\
\hline
\end{tabular}

\begin{tabular}{|c|l|c|c|c|}
\hline & $\begin{array}{l}\text { membuat alat } \\
\text { peraga dengan } \\
\text { baik. }\end{array}$ & & & \\
\hline 10 & $\begin{array}{l}\text { Saya merasa } \\
\text { senang } \\
\text { mengikuti } \\
\text { kegiatan } \\
\text { pelatihan ini. }\end{array}$ & 28 & 4 & $\begin{array}{l}\text { Sanga } \\
\text { t Baik }\end{array}$ \\
\hline & Jumlah & 263 & 37,58 & \\
\hline Rerata & 26,3 & 3,76 & $\begin{array}{l}\text { Sanga } \\
\text { t Baik }\end{array}$ \\
\hline
\end{tabular}

Beberapa temuan pada pengabdian kepada masyarakat ini antara lain sebagai berikut:1) Semua peserta belum pernah menggunakan alat peraga IPA sederhana yang telah dirancang oleh Tim Pengabdi, 2) Sebagian besar peserta pelatihan dalam membelajarkan IPA tanpa menggunakan alat peraga, 3) Semua peserta pelatihan masih belum terbiasa untuk merancang dan membuat alat peraga IPA, dan 4) Setelah mengikuti pelatihan para peserta dapat memiliki wawasan bahwa alat peraga IPA sederhana dapat dibuat dengan biaya murah dengan berbasis lingkungan.

Setelah mengikuti kegiatan pelatihan ini ditemukan beberapa hal yang positif terkait dengan alat peraga IPA sederhana sebagai berikut: 1) Mendapatkan pengetahuan tentang perancangan pembuatan alat peraga IPA sederhana berbasis lingkungan, 2) Memperoleh pengetahuan dan keterampilan dalam menggunakan alat peraga IPA sederhana, dan 3) Antar peserta pelatihan dapat melakukan sharing pengetahuan dan keterampilan tentang perancangan dan penggunaan alat peraga IPA sederhana.

Berdasarkan pada Tabel 1 tampak bahwa kinerja peserta pelatihan dalam merancang dan membuat media pembelajaran IPA sederhana dalam aspek kerjasama, keaktifan, kesungguhan, dan kualitas produk, semuanya dalam kategori sangat baik. Hal ini berarti bahwa semua peserta pelatihan betul-betul sangat membutuhkan materi yang disajikan pada kegiatan pengabdian.

Selanjutnya berdasarkan pada Tabel 2 tampak bahwa materi pelatihan, metode 
penyampaian materi, penguasaan materi instruktur, fasilitas yang disediakan, tantangan yang diberikan pada saat pelatihan, kebermanfaatan pelatihan, dan materi pelatihan yang disajikan semuanya mendapatkan respon sangat baik dari peserta. Sementara itu alokasi waktu pelatihan, dan keterampilan membuat alat peraga IPA setelah mengikuti pelatihan, keduanya mendapatkan respon yang baik dari peserta.

Penggunaan media selama pembelajaran di sekolah diharapkan dapat memfasilitasi dan meningkatkan kualitas pembelajaran. Dampak praktis ketika media pembelajaran berkualitas tinggi digunakan sebagai bagian integral di kelas adalah : (1) isi sebuah topik diseleksi dengan lebih hatihati dan diorganisasikan, (2) penyampaian materi dapat lebih terstandar, (3) pembelajaran lebih menarik, (4) belajar menjadi lebih interaktif, (5) pembelajaran yang memerlukan waktu panjang dapat direduksi, (6) kualitas belajar dapat diperbaiki, (7)pembelajaran dapat diulang pada waktu dan tempat yang diinginkan, (8) sikap positif individuterhadap apa yang dipelajari dan proses belajarnya dapat ditingkatkan, dan (9) peran guru dapat ditingkatkan [2]. Berpijak dari uraian di atas penggunaan media dapat membuat suasana belajar menjadi lebih menarik, menyenangkan, dan bermakna bagi peserta didik. Dengan demikian penggunaan media dapat memberikan kontribusi dalam pencapaian tujuan pembelajaran.

Guru yang profesional selalu menggunakan cara-cara kreatif dalam memyampaikan materi pelajaran, termasuk kreatif dalam menggunakan media pembelajaran. Semakin banyak media yang digunakan guru memberikan indikasi bahwa mutu pembelajarannya semakin meningkat. Media pembelajaran yang berkualitas tinggi adalah media yang pengembangannya melalui proses seleksi, desain, produksi, dan digunakan sebagai bagian integral dari sistem instruksional. Sedangkan menurut Heinich (1992) pengembangan media dapat menggunakan model ASSURE yakni : analyze learners, state objectives, select media and material, utilize material, require learners performance, dan evaluate/revise [3].

\section{KESIMPULAN}

Kesimpulan yang dapat ditarik dari kegiatan pengabdian ini adalah: 1) Peserta pelatihan mendapatkan pengetahuan tentang perancangan alat peraga IPA sederhana berbasis lingkungan, 2) Peserta pelatihan memperoleh keterampilan untuk membuat alat peraga IPA sederhana, dan 3) Peserta pelatihan mendapatkan keterampilan dalam menggunakan media pembelajaran IPA sederhana.

\section{UCAPAN TERIMA KASIH}

Ucapan terima kasih kami sampaikan kepada Universitas Negeri Yogyakarta yang telah mendanai kegiatan pengabdian ini dengan dana DIPA UNY tahun 2016.

\section{PUSTAKA}

Bourden, Paul R. 1998. Method for Effective Teaching $2^{\text {nd }}$. Allyn and Bacon, Boston.

Heinich, Robert. 1989. Instruction Media and The New Technologies Instruction, Third Eddition. Macmillan Publishing Company, New York.

Mohammad Amin, dkk. 2013. Bahan Pelatihan Pengelola Laboratorium Sekolah Menengah Pertama. Modul. Jakarta: Kemendikbud. 